Wegene Demeke*, Anthony Olden and Jose Abdelnour Nocera

\title{
Factors Affecting the Adoption of Information and Communication Technologies: Small Hotels and Tour Operators in Addis Ababa, Ethiopia
}

DOI 10.1515/libri-2016-0029

Received March 22, 2016; revised April 16, 2016; accepted April 18, 2016

\begin{abstract}
In Africa the adoption of Information and Communication Technologies (ICTs) varies considerably from one country to another, for example between Kenya and Tanzania on the one hand and Ethiopia on the other. In Kenya and Tanzania telecommunications systems have been liberalized, while in Ethiopia all ICT infrastructures and services are provided by one single telecommunications operator - one that is owned and run by the government. ICT plays a significant role in poverty reduction and empowerment of the disadvantaged, but this requires that ICT has first to be adopted by them. The main research question is: what are the factors affecting the adoption of ICT in the small hotel and tour operator sector? The purpose of this paper is to examine the factors that affect the adoption of ICT in small hotels and tour operators in Ethiopia's capital city, Addis Ababa. The sector was chosen because, driven by demand from customers, it uses ICT more than many other sectors, and because the government requires hoteliers to use a particular software for tax purposes. During the course of several visits between 2009 and 2013 data were collected from hoteliers and tour operator owners/managers. Sixteen hoteliers who had adopted ICT in their businesses were interviewed. One hundred and twenty-eight hoteliers and 57 tour operators responded to a questionnaire. Analysis of the findings indicates that factors affecting the adoption of ICT in these organizations can be arranged according to three levels: individual, organizational and national. The major factors that affect the adoption arise from the national level factors: the political, socio-economic, technological
\end{abstract}

*Corresponding author: Wegene Demeke, Department of Computing, Buckinghamshire New University, Queen Alexandra Road, High Wycombe HP11 2JZ, UK, E-mail: wegene.demeke@gmail.com Anthony Olden, Institute for Practice, Inerdisciplinary Research and Enterprise, University of West London, St Mary's Road Ealing, London W5 5RF United Kingdom of Great Britain and Northern Ireland, E-mail: Tony.Olden@uwl.ac.uk

Jose Abdelnour Nocera, School of Computing and Technology, University of West London, London, United Kingdom of Great Britain and Northern Ireland, E-mail: jose.abdelnour-nocera@uwl.ac.uk and legal factors that play a critical role in the adoption or rejection of ICT in this sector. This paper provides insights into the impact a monopolized telecommunications service can have on the adoption of ICT.

Keywords: national factors, ICT, small hotels, tour operators, Addis Ababa, Ethiopia

\section{Introduction}

The role of ICT as a facilitator and as an enabling tool for the reduction of poverty and the empowerment of the poor and marginalized is recognized by such international organizations as the United Nations (UN), the World Bank (WB) and the International Telecommunication Union (ITU). However, ICT diffusion in the developing countries lags behind the developed countries because of a range of factors, the result being the "digital divide." This is particularly the case in Ethiopia, where all ICT infrastructures and services are provided by one single telecommunication operator, which is owned and run by the government. Against the background of very low ICT adoption in Ethiopia, the research reported in this paper sets out to investigate the relationship between political, socio-economic, technological - in particular, telecommunication - and legal factors and ICT adoption and use by small hotels and tour operators in Addis Ababa. The anticipated contribution to knowledge includes identification of the factors that facilitate or militate against the takeup of ICT in this particular sector.

Comparisons are made with selected Sub-Saharan countries. Ethiopia's telecommunication sector operates as a monopoly, whereas Kenya and Tanzania have liberalized telecommunications. Kenya and Tanzania have had democratically elected governments since independence in the 1960s, whereas Ethiopia had a monarch and then a Marxist army officer until the latter was driven out in 1991. All three countries are non-oil economies. Other countries such as Eritrea, Somalia and Sudan were considered for comparison but ruled out. Sudan is an oil-based economy with a liberalized telecommunication sector. Eritrea has a monopolistic telecommunication infrastructure with limited available data on ICT diffusion. Somalia is a failed state. It has not 
had a functioning government since the 1980s, and part of it seceded as the Republic of Somaliland in the early 1990s. However, the war in Somalia and repressive government in Eritrea have resulted in large diasporas notable for their enthusiastic adoption of modern telecommunications (Issa-Salwe and Olden 2008).

\section{Level of ICT in Ethiopia}

The ICT Development Index (IDI) shows the ranking of Ethiopia compared to other countries. The data indicate that the Ethiopia's rank remains the same at 150 out of 157 countries for 2010 and 2011. The IDI ranking for Ethiopia shows a reduction from 150 to 151 during 2012. The IDI indicator shows a slight improvement from 1.22 to 1.24

Table 1: ICT development index.

\begin{tabular}{lrrrrrr}
\hline Economy & Rank & IDI & Rank & IDI & Rank & IDI \\
& $\mathbf{2 0 1 2}$ & $\mathbf{2 0 1 2}$ & $\mathbf{2 0 1 1}$ & $\mathbf{2 0 1 1}$ & $\mathbf{2 0 1 0}$ & $\mathbf{2 0 1 0}$ \\
\hline Uganda & 130 & 1.81 & 130 & 1.72 & 136 & 1.53 \\
Rwanda & 141 & 1.66 & 143 & 1.54 & 140 & 1.5 \\
Zambia & 132 & 1.77 & 137 & 1.64 & 137 & 1.53 \\
Mauritania & 133 & 1.76 & 133 & 1.7 & 138 & 1.53 \\
Cameroon & 136 & 1.72 & 136 & 1.66 & 135 & 1.54 \\
Tanzania & 142 & 1.65 & 141 & 1.57 & 139 & 1.52 \\
Congo (Rep. of the) & 147 & 1.31 & 146 & 1.3 & 133 & 1.55 \\
Benin & 143 & 1.6 & 142 & 1.57 & 141 & 1.49 \\
Madagascar & 149 & 1.28 & 147 & 1.28 & 142 & 1.41 \\
Malawi & 145 & 1.43 & 145 & 1.41 & 143 & 1.37 \\
Mali & 144 & 1.54 & 144 & 1.43 & 147 & 1.24 \\
Congo (Dem. Rep.) & 147 & 1.31 & 146 & 1.3 & 149 & 1.18 \\
Mozambique & 148 & 1.31 & 149 & 1.26 & 145 & 1.26 \\
Guinea & 152 & 1.23 & 151 & 1.2 & 146 & 1.25 \\
Liberia & 146 & 1.39 & 148 & 1.27 & 148 & 1.2 \\
Ethiopia & 151 & 1.24 & 150 & 1.22 & 150 & 1.09 \\
Burkina Faso & 154 & 1.18 & 154 & 1.11 & 152 & 1.06 \\
Eritrea & 153 & 1.2 & 153 & 1.15 & 151 & 1.08 \\
Central African Rep. & 156 & 1.00 & 155 & 1.00 & 153 & 0.96 \\
Chad & 155 & 1.01 & 156 & 0.94 & 155 & 0.85 \\
Niger & 157 & 0.99 & 157 & 0.93 & 154 & 0.88 \\
\hline Source: & & & & & &
\end{tabular}

Source: ITU (2013a). between 2011 and 2012. The average IDI value change between 2011 and 2012 is 0.2, whereas in the case of Ethiopia it is just 0.02 (Table 1). This indicates that Ethiopia's ICT development is lagging behind other countries. The data from ITU indicate the low-level penetration of ICT in the country (ITU 2013a).

The growth of mobile phones and the Internet in the developing world has been remarkable, but the figures for Ethiopia are disappointing when compared with those of other Sub-Saharan countries. At the end of 2012, as shown in Table 2, mobile phone users as a proportion of the population in Kenya amounted to $71.9 \%$. In Tanzania, the figure was $57.1 \%$, whereas in Ethiopia it was $23.7 \%$. A high proportion of individuals living in Kenya (32.1\%) had access to the Internet. In Tanzania, the figure was $13.1 \%$ but in Ethiopia it was just $1.5 \%$. The telecommunication sector has been liberalized in most African countries, including Kenya and Tanzania. Ethiopia, however, is among the three countries in Africa that maintain restrictions on Foreign Direct Investment (FDI) in the telecommunication sector, the others being Eritrea and Djibouti.

The ITU report on measuring the information society provides a comparison of ICT development among countries. The report encourages governments to examine their telecommunication policies. These recommendations and conditions are not welcomed by all. For example, the government of Ethiopia responded as follows through $\mathrm{Dr}$ Debretsion Gebremichael, Minister of Communication and Information Technology: "ICT is developing in Ethiopia, the method used by ITU is not accurate enough to measure its progress" (Mekonnen 2013). This shows that the Ethiopian government argued about the methodology used by ITU to measure the digital divide rather than acknowledging the lack of diffusion.

\section{ICT Policies}

Batchelor et al. (2005) argue that government policies have to focus on building the ICT infrastructure. As to how to

Table 2: Comparison ICT indicators for selected Sub-Saharan countries.

\begin{tabular}{|c|c|c|c|c|c|c|c|c|c|c|c|c|}
\hline & \multicolumn{3}{|c|}{$\begin{array}{r}\% \text { of individuals using the } \\
\text { Internet }\end{array}$} & \multicolumn{3}{|c|}{$\begin{array}{r}\text { Fixed telephone } \\
\text { subscribers per hundred } \\
\text { inhabitants }\end{array}$} & \multicolumn{3}{|c|}{$\begin{array}{l}\text { Mobile phone subscription } \\
\text { per hundred inhabitants }\end{array}$} & \multicolumn{3}{|c|}{$\begin{array}{r}\text { Percentage of household } \\
\text { with computer }\end{array}$} \\
\hline & 2010 & 2011 & 2012 & 2010 & 2011 & 2012 & 2010 & 2011 & 2012 & 2010 & 2011 & 2012 \\
\hline Ethiopia & 0.8 & 1.1 & 1.5 & 1.1 & 1 & 0.9 & 8.3 & 16.7 & 23.7 & 1.4 & 1.8 & 2.1 \\
\hline Kenya & 14 & 28 & 32.1 & 0.9 & 0.7 & 0.6 & 61.6 & 64.8 & 71.9 & 5.6 & 7.8 & 8.8 \\
\hline Tanzania & 11 & 12 & 13.1 & 0.4 & 0.3 & 0.4 & 46.8 & 55.5 & 57.1 & 3.6 & 4 & 4.4 \\
\hline
\end{tabular}

Source: ITU World telecommunication/ICT indicators database ITU (2013a). 
minimize the effects of the barriers, they recommend two factors that would enable the full potential of ICTs to reduce poverty. Firstly, ICT capacity building by mainly government and other stakeholders needs to be accelerated. Secondly, ICT content should focus on health, education and the creation of favourable economic conditions. However, according to Chisenga (1999), in Sub-Saharan Africa governments ignore ICT or deliberately limit the availability of information.

The Plan for Accelerated and Sustained Development to End Poverty (PASDEP) outlined the national telecommunication policy of the Ethiopian government. This plan ran from 2005 to 2010. The Growth and Transformation Plan (GTP), which followed, ran from 2010 to 2015. It underlined the importance of telecommunication services for development and poverty reduction. There were five elements in its strategy:

- promoting human resource development in the ICT field;

- mainstreaming the use of ICT in all sectors of the economy, in the administration of government, and in the education system;

- developing the necessary telecommunication infrastructure;

- promoting research and development through ICT;

- and creating the enabling legal and regulatory framework.

However, the strategy failed to identify how these five elements could be achieved. It further stated that $85 \%$ of the country's population lives in the rural areas. The rapid development of the rural economy depends on access to an adequate level of telecommunication services. According to the PASDEP document, the aim was to develop rural telecommunications and provide basic telephone and data services for 300 rural towns. Public access to telecommunication services was to be increased.

The documents acknowledge that developing telecommunication service coverage requires a considerable level of investment in terms of technology and expertise. To do so, the government intended to engage with a strategic partner in the development of telecommunication infrastructure. In June 2010, France Telecom took over the management of Ethiopian Telecommunication. Although the number of telecommunication subscribers grew, the growth in numbers and service provision was not as significant as in other Sub-Saharan countries. Government ownership, regulation, the absence of competition and tariff policies remained the same: a government-owned public telecommunication organization and a semi-autonomous regulator, both reporting to the same government ministry.

Liberalization, regulation and competition in the telecommunication sector increase the availability of services and growth of infrastructure as a result of the higher level of investment. This is generally followed by a lower tariff (Maiorano and Stern 2007; Fink et al. 2003). Stern and Trillas (2003) argue that independence of the telecommunication regulator results in better services in the sector. The historical data have not yet sufficiently indicated the gain from an independent regulatory framework. However, Stern and Trillas (2003) argue that poor regulatory framework in developing countries affects the industry negatively:

We can show the disasters that result from regulatory arrangements with poor governance, including the bad outcomes arising from wide, non-accountable discretion, particularly in developing countries. (Stern and Trillas 2003, 201)

Furthermore, ICT's role is expanding in other areas as a result of technological innovations, thus creating new channels of communications such as the social media. This empowers individuals and groups, which in turn attracts the attention of governments. The government of Ethiopia keeps close control on the use of ICT in the country. After the 2005 disputed election, ETC stopped text service throughout the country. Though the government did not provide any explanation for this service suspension, one can assume that the opposition used texting to organize their campaign before the election (Blunt 2007). Texting service resumed in 2007 after two years of complete absence. In 2012, Skype and similar voice-over-IP services became illegal and a crime punishable by fifteen years of imprisonment (Moskvitch 2012). The recent report by the Committee to Protect Journalists (CPJ) indicates that censorship of information flow in Ethiopia is on the increase. News websites and blogs are increasingly banned by new pervasive filtering systems in the country.

\section{National Level Factors Affecting Adoption or Rejection of ICT}

The factors that affect the adoption of ICT by individuals or organizations can be divided into two: those that are external to the individual or organization and those that are internal (Lefebvre and Lefebvre 1996). The factors behind adoption or rejection are shown in Figure 1. The internal factors are divided into three: the worker, 


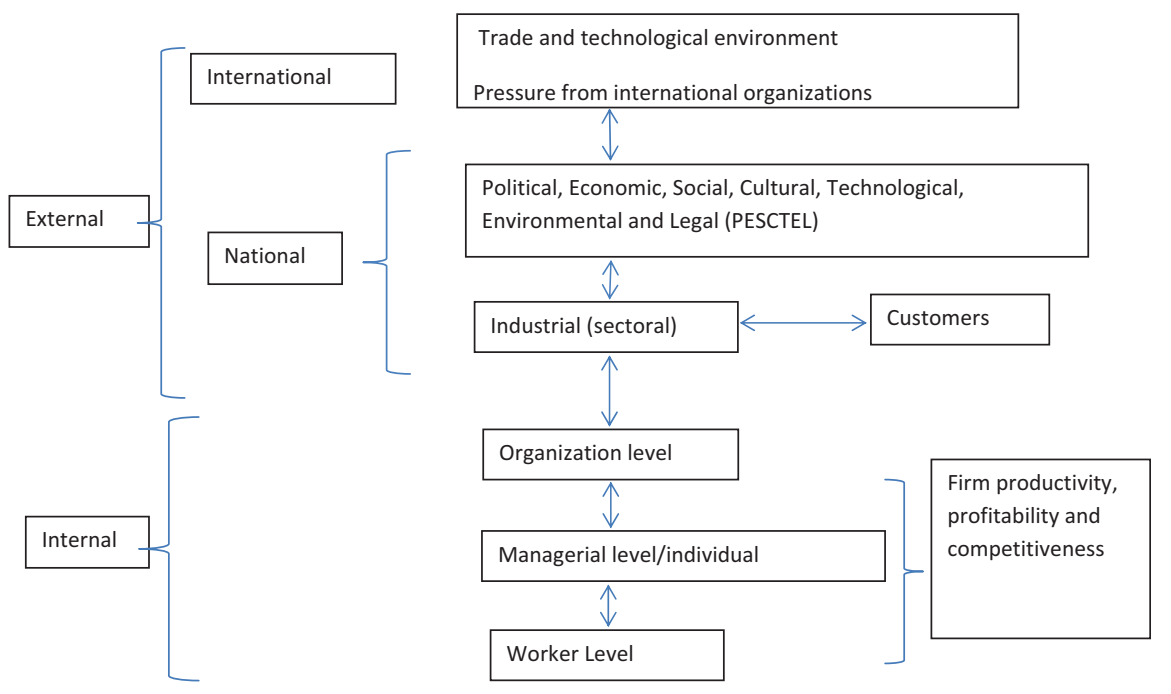

Figure 1: Levels of determinants of technology adoption; adopted and modified from Lefebvre and Lefebvre (1996, 29).

the managerial and the organizational. In the case of micro and small organizations, the internal adoption factor is mainly influenced by the characteristics of the owner/manager of the establishment. However, the workers in these establishments have some input, such as in contributing to the technical knowledge or influencing the owner/manager to adopt or reject the innovation.

External level factors are outside the control of individuals and organizations. They can be divided into three. Firstly, at the industrial level, the main focus is on the particular factors affecting the sector to which the organization belongs. For example, the hotel and tour operators sector has different characteristics from the manufacturing sector. Secondly, at the national level, the Political, Economic, Social, Cultural, Technological, Environmental and Legal (PESCTEL) factors play a critical role in the diffusion of innovation in the country. These factors are specific to that particular country. Thirdly, on the international front, the factors arise because of the characteristics of innovations that cross national boundaries and hence are governed by international agreements. These agreements determine the technical standards and pricing of services offered by these systems. International organizations have prescribed policies, particularly for developing countries, on many areas including telecommunications and the structure of the electric power sector. Though these prescriptions have been criticized for being "one fit for all," they put pressure on developing countries to change policies. The focus of this paper is on the national level factors that affect the adoption of ICT.
Many researchers argue that at the national level, PESCTEL factors play a significant role in the adoption of ICT. This is particularly the case in developing countries (see for example Estache etal. 2009; Maiorano and Stern 2007; Gasmi etal. 2009; and Gagliardone 2014). Furthermore, ICT availability, pricing and technical support are all affected by these factors. The telecommunication policy and strategy on the national level set out how the market operates: the liberalization, competition and independent regulation of the market.

The Broadband Commission (2013) argues that countries which have a liberalized market have a higher level of uptake of broadband services, $1.4 \%$ higher on average for fixed broadband and up to $26.5 \%$ higher for mobile broadband. Its other recommendations include reviewing and reducing taxation. The Commission argues that the revenues raised by taxation of ICT services and devices are more likely to be lower than the broader economic advantages obtained through greater use of telecommunication services. These recommendations are controversial. Gagliardone (2014) argues that some recommendations by international organizations tend to benefit big companies rather than developing countries.

\section{Political Factors}

The telecommunications policy of a nation determines how the sector functions, including its ownership and competitiveness. This condition determines the affordability and availability of ICT and plays a critical role in the adoption 
and diffusion process. The ability of national political conditions to reform the telecommunication policy depends on how the political system is organized. Li et al. (2005) argue that the political structure - and especially the decisionmaking apparatus and the ideology of the legislature plays a critical role in opening up the market. Furthermore, reform in the sector is less likely in countries where the incumbent operators have already made a large investment. In addition, Galal and Nauriyal (1995) and Levy and Spiller (1996) argue that the political structure and the configuration of interest groups determine the likelihood of telecommunication reform. There is a high level of investment in Ethiopian telecommunication. China's Zhanxing Telecom Corporation (ZTE) invested $\$ 1.3$ billion dollars. Whether this will be a hindrance for the liberalization of Ethiopian telecommunications will become clear in the future (Davison 2012).

The political context of a country determines how the telecommunication sector is organized and functions. Gasmi etal. (2009) point out that the quality of the political institutions, that is the political accountability, is a key factor in creating a strong regulatory body for the telecommunication sector. Countries that have accountability in their political system create a strong and effective regulatory body. By contrast, Maiorano and Stern (2007) argue that the choice of a regulatory framework based on a country's institutions leads to no convincing conclusion. However, Henisz and Zelner (2001) argue that a country's political institutions play a critical role in how telecommunication services operate.

Williamson (1994) argues that if authoritarian regimes find telecommunication reform provides political benefits it is easier to reform the sector. In Ethiopia, the governing party has been in power since 1991 . Although elections are conducted every five years, the conditions created by the government are not conducive to true democratic processes. Gagliardone (2014) studied the adoption of two large-scale ICT projects in Ethiopia, WoredaNet and Schoolnet. WoredaNet is a network that connects all district administrative offices to the prime minister's office. Schoolnet is a similar network used to transmit pre-recorded classes to high schools throughout the country. The adoption and implementation of these projects are driven by the ideology of the government of Ethiopia to build ethnic-based federalism. ICT is used as a tool for extending the political power of the government. This study also confirms what Winner (1980) says about technology and politics: politics plays a significant role in the uptake of ICT. A South African study indicates that politics plays an important role in how telecentres are planned and managed, and how this is empowering certain users but not others (Braathen et al. 2012). These studies indicate the significant role played by politics in the adoption of technology, and this research investigates the factors affecting ICT adoption in the hotel and tour operators sector that originate from organizational, individual and PESTEL levels.

\section{Socio-economic Factors}

The economic policies practised by governments and their results, such as the general economic condition, inflation management, corruption and the exchange rate, affect how organizations and individuals adopt ICT. These economic factors affect the diffusion of innovations differently: some innovations diffuse easily while others fail completely. In addition, the economic effects also vary for different social groups. A nation's economic policies affect diffusion of innovation. For example, tax policies affecting innovations that have to be imported can discourage organizations and individuals from adopting them. General economic conditions determine the trend in pricing and affordability of the innovation, which affects an organization's ability to adopt it (Gurbaxani and Mendelson 1990). Krieg (1995) argues that widespread low-level economic conditions result in a deficiency of material wealth, which in turn inhibits the adoption of technology in poor communities.

The telecommunication sector is growing continuously, according to ITU (2013b) the revenue from services in this sector contributes $4 \%$ of GDP in Sub-Saharan countries. In many cases, there is a positive relationship between GDP per capita and adoption of an innovation by organizations and individuals. The higher the GDP per capita of a nation, the more likely that innovation adoption increases by organizations and individuals (Billon et al. 2009). Its influence is further enhanced by the development of the Internet. This provides access to information and has the ability to organize individuals and social groups to empower them to influence political and social issues.

\section{Telecommunication Factors}

Between 1985 and 1999 many developed countries reformed their telecommunication policies, resulting in the improvement of their telecommunication networks. As a result, both teledensity and labour productivity more than tripled (Fink et al. 2003). The rapid growth of 
technological innovations in the past three decades transformed how individuals and organizations communicate, work and interact. Traditional telecommunication services have been transformed beyond recognition, changing the generation, transformation and communication of information, and creating instant communication between individuals and organizations. One of the barriers to the adoption of technology in the Least Developed Countries (LDC) is the unreliable telecommunication infrastructure. Karanasios and Burgess (2008) show how SME owners use innovative methods to overcome the inadequate and unreliable infrastructure by using a satellite link to connect to their customers.

The adoption of ICTs can have unanticipated effects for individuals, groups and organizations. As Soper and Demirkan (2012) argue, the effects of the mobile phone on fostering democracy and empowerment in the emerging countries were not anticipated - and yet it does just that. The Internet provides transparency, thus curbing corruption. For example, in Kenya and elsewhere in Africa, the use of the mobile phone for finance was not part of the design for mobile phones, and yet it fulfils this purpose (Ngugi et al. 2010). Furthermore, the unanticipated effects of ICT adoption encompass many areas, including the social, economic and political sphere of a nation.

\section{Legal Factors}

The lack of legislation dealing with emerging technologies has been noted in both developed and developing countries and is more pronounced in the latter (Ng'ang'a 2009). According to Ng'ang'a, Kenya had no legislation to deal with threats arising from identity theft, computer crime, money laundering and fraud. On the other hand, government intervention through regulations can be a positive force for research into the development of new products, for example in the case of dangerous substances. Taylor etal. (2003) instance the research and development of environmental control technology for hazardous substances such as sulphur dioxide (SO2) and the results of the diffusion of innovations of such technology. The law forces organizations to adopt the new technology.

\section{Methods}

An exploratory initial visit to Addis Ababa investigated the adoption of ICT by various sectors of the economy.
The hotel sector was decided upon for the reasons given earlier in the Introduction. Mixed methods research methodology was found to be appropriate for this study in two ways. Firstly, the qualitative data helped to explore the phenomenon under investigation. Secondly, the survey data provide the factors that affect the adoption of ICT from a large sample, complementing the qualitative method. Other researchers (Ridenour and Newman 2008; Teddlie and Tashakkori 2009) argue that the use of mixed methods research is advantageous in a number of ways: qualitative and quantitative methods provide better or stronger inferences than the single method. The qualitative method provides rich narratives, deep insights into the phenomenon under study. The quantitative method provides breadth to a study by providing data from a much larger sample, and from various focused areas of key aspects of the phenomenon not covered in the qualitative method. The use of mixed methods can provide better inferences (Venkatesh et al. 2013). The most important advantage of this method is its ability to provide triangulation of qualitative and quantitative data to develop a deeper understanding of the phenomenon under investigation (Denzin 2006; Silverman 2005; Stake 1996).

A second visit sought out research participants from the hotel sector: some hoteliers agreed to participate but no government-run organization was willing to be involved. Tracking down hotels and tour operators proved complex. The city is divided into ten administrative regions. However, many hotels and tour operators tend to concentrate near the airport, or where international organizations are located. It proved difficult to locate many small hotels because the Ministry of Trade and Industry lists are not up-to-date and the Ethiopian Mapping Agency does not provide detailed maps. Local Administrative offices were consulted, local contacts assisted, and snowballing was used.

On a third visit, the intention was to interview the person who made the decision to adopt or reject ICT, or at least knew the reasons that led to the decision. Face-toface interviews were conducted with 16 hoteliers who had adopted ICT in their businesses.

On a fourth visit data were gathered by questionnaire from hoteliers and tour operators with the assistance of a locally based research assistant, an individual with more than twenty years' experience of collecting data for the Ethiopian Central Statistics Agency. The assistant continued the work, and ultimately data were gathered by questionnaire from a total of 128 hoteliers and 57 tour operators. The first author or the research assistant went through the questionnaire with the respondents and 
wrote down the answers. Questions were in Amharic and translated into English. The questionnaire covered the following:

- demographic data;

- hotel or tour operator details;

- perception of ICT knowledge;

- ICT adopted tools and use;

- ICT adoption or resistance to adoption factors;

- impact of ICT;

- information-seeking behaviour.

The qualitative data were analysed using NVivo software: first ideas were coded, and then themes identified using similar codes. The data were collected and coded by the first author. This is an exploratory study, and hence inductive coding was used for the generation of the categories from the data itself (Miles and Huberman 1994). Being an exploratory study, it was not possible to generate categories prior to data collection. Inductive coding was found to be appropriate for the analysis. To verify coding consistency, part of the data was re-coded by the same author after a lapse of a few months and the results compared. A high level of coding similarity was found. Furthermore, triangulation was used to confirm findings from the survey methods and sources of information to confirm the validity of coding.

In the case of quantitative data, SPSS was used to analyse data, then both findings compared and aggregated to come up with the factors that cause the adoption of ICT and the factors that hinder its adoption.

Because the first author has contacts in Addis Ababa and his first language is Amharic, it was assumed that the fieldwork would be straightforward. This did not prove to be the case. Initial e-mails in Amharic to owners/managers of hotels were almost all ignored. Face-toface approaches proved more successful, but it often took a number of visits before the interview took place. Government employees were afraid to say anything that might be interpreted as criticism. These and other issues associated with the conduct of the research have been reported elsewhere (Demeke and Olden 2012).

A fifth visit to Addis Ababa provided the opportunity to discuss findings in person with the research assistant. The five visits were made between 2009 and 2013.

\section{Overview of Findings}

The findings presented here are based on the data collected using survey and interview methods. The findings indicate that factors affecting the adoption of ICT can be arranged according to three levels: the individual, the organizational and the national. The purpose of this paper is to focus on the national level factors. These have a direct influence on the individual and the organization. The political decision as to whether the telecommunication market structure should be liberalized or monopolized has a direct influence on competitiveness, ICT availability and price. This, coupled with the general national economic condition, affect individual and organizational attitude towards and capacity for ICT adoption.

The adoption of ICT among the surveyed owners/ managers of both hoteliers and tour operators are presented in Table 3, followed by the national factors that affect the adoption of ICT. The survey results indicated that tour operators adopt ICT more than hoteliers.

Table 3: Percentages of adopters among hoteliers and tour operators.

\begin{tabular}{lrrrrr}
\hline & Mobile & Computer & Broadband & Website & E-mail \\
\hline Hoteliers & 100 & 35.2 & 14.8 & 12.5 & 32.5 \\
Tour operators & 100 & 100 & 98.2 & 93 & 98.2 \\
\hline
\end{tabular}

The data indicate that many of the small hoteliers are not adopters of ICT. Reasons include lack of knowledge and absence of demand for the technology from their customers.

When one considers the knowledge of hotelier and tour operator owners/managers, the data indicate that $45 \%$ of hoteliers had secondary education, while $43 \%$ of tour operators had an undergraduate degree. The data also indicate that $100 \%$ of tour operators adopt technology, whereas only $35 \%$ of hoteliers adopt computers in their businesses. It seems that tour operators are greater adopters of ICT in comparison with hoteliers. The level of education seems to be one of the factors that affect the adoption of ICT in the sector. The study by Mokaya (2012) on the adoption of ICT in small enterprises in Kenya showed similar results, that level of education and knowledge has a significant effect on adoption. However, Raho et al. (1987) argue that educational commitment - the continuing learning by potential adopters of new innovation - has a more significant effect on adoption.

This research found that the least adopted technology was the one imposing the greatest knowledge demands on would-be adopters: websites (12\% adoption by hoteliers) and broadband (14\% adoption by hoteliers). 
Computers (35\% adoption) required a lower level of knowledge on the part of would-be adopters, resulting in a higher level of adoption. Other researchers had similar results: the higher the level of knowledge required, the less likely the technology would be adopted (Attewell 1992; Cohen and Levinthal 1990).

There is a gender divide in education. Though the situation is improving, there are deep-seated differences in gender enrolment at school. Families tend to send boys to school rather than girls. The data from this study indicate that for hoteliers $19 \%$ were female and $81 \%$ male. In the case of tour operator owners/managers, $53 \%$ were male and $47 \%$ female. The gender distribution in this sector of the economy shows gross under-representation of women in top management, especially in decision-making positions. In addition, the majority of women work for many hours in labourintensive jobs with the least amount of pay.

\section{Lack of Finance}

The difficulties experienced by SMBEs in raising finance for improvement and investment are well documented, and it is even more difficult in developing countries. Some respondents $(14 \%)$ indicate that lack of finance is a major factor for non-adoption of a computer in their establishments. One respondent described the situation with the lack of finance as follows: "we are limited by the lack of finance, on what we do, we struggle to pay our rent". Another respondent stated: "there is always a lack of finance". Another made the same point: "this is a very small hotel and lacks financial strength".

The price of a computer is not cheap. This is a result of many factors, including $40 \%$ import tax and an inflation level of $24 \%$ (2012), which make a PC unaffordable, particularly for small hotels. Many respondents reiterated the lack of affordability of a computer, as one respondent pointed out: "we do not have the ability to finance the purchase of a computer". Other respondents mentioned the additional expense associated with the ownership of a computer. Hotels are required to employ new staff that have the skills and knowledge to use a computer, or provide training for existing staff. This is an additional expense for a small hotel:

... buying a computer requires the hiring of other staff with skills and knowledge to use it, and we do not have the finance to do this. (Manager)

We do not have the financial capability of employing a computer operator in our hotel. (Owner)

There is no budget to employ staff to operate a computer. (Manager)
In addition, a computer requires regular maintenance and updating from time to time to keep it in working order and to protect the data from viruses and unwanted programmes. This is an additional expense for hoteliers. Although hoteliers use computers, when they malfunction it may not be possible to maintain them because of lack of money. One respondent explained the problem as follows:

We bought a computer and we were using it for a while but now it is faulty and we are unable to fix it. (Manager)

\section{High Price}

The prices for telecommunications services are falling in the sector; the latest figures from ITU indicate that in the last four years there has been a reduction of $82 \%$ in the price of broadband. The price in Ethiopia has dropped but it is still too expensive for many people. The price of broadband as a percentage of GNI per capita was $85 \%$ in 2011; in 2013, the price had dropped to $71 \%$ of GNI per capita (ITU 2013a). The government imposes $40 \%$ tax on all imported ICT equipment. This makes ICTs unaffordable. Price plays a significant role in the adoption of ICT, and high price acts as a resistance factor for the adoption of ICT. Mokaya (2012) confirms this result, that the perception of high price by owners/managers restricts adoption.

\section{Monopoly}

ETC is the only telecommunications company in the country that provides telecommunications products and services including telephone, fax and Internet services. The choice is very limited. As one respondent stated:

The telecommunications company has an absolute monopoly. (Manager)

According to another:

In Ethiopia we have one telecoms operator and I do not think that they can provide the service for everyone. In other countries, it would be unthinkable to have a single telecoms operator. The Internet speed is $256 \mathrm{~KB} / \mathrm{s}$, but it is less than that. (Manager)

The monopoly is not limited to the telecommunications service; in the hotel sector for example, the software that manages the reservation, check in and check out systems, food and beverage sales, and control system, is supplied by CNET Technologies PLC. The software, CNET, is supplied to hotels by Property Management System (PMS), 
and is the only software supplier to all hotels except the international chain hotels such as the Hilton and Sheraton. The CNET software installed in every hotel is directly connected to the Ministry of Inland Revenue. All sales are transmitted live to the Ministry Office for tax collection purposes. The government have given CNET a monopoly to supply, maintain and provide training on the software, at least for non-international hotels. The following interviewees expressed this view as follows:

In my understanding, CNET initiated the process of supplying software to the hotel business and requested recognition from the government that is how it started. It is a very active company, I think the government does not know or understand the consequences, or it may be the case that a decision is made to support the company by the government. Now, CNET has the biggest market share of hotel software in Ethiopia. (Manager)

CNET software diffusion is a result of the government's recognition of this company and also because the government wants it to be used. CNET provides the software, training and maintenance. It connects all the operations of the restaurant, bar and reception. I can monitor what is going on in all areas from my PC, whenever there is a problem. (Manager)

Reporting faults and maintenance of the CNET software is a sensitive issue according to respondents. Only the staff of CNET are allowed to install, upgrade or maintain the software. One of the interviewees explained the relationship between the hotelier and the software supplier as follows:

We call them whenever there is a problem and they sort it out; it costs a lot of money. There is a circular from the government that no-one is allowed to perform maintenance on the system, especially on the CNET software. The system is connected to the tax office, and sales are reported directly as they happen. If I want to employ staff to maintain the CNET system, it has to be on a part time basis and can only be a member of staff working for the CNET Company. (Manager)

The following respondent described the problem, which is not restricted to ETC but extends to the Ethiopian Electric Power Corporation (EEPC). EEPC has a monopoly on the supply, generation, distribution and maintenance of electricity in the country as well:

The telecoms operator is unable to provide the service or maintain the existing network. Recently, a new hotel was preparing to launch its service, but there was no telephone line so the owner was using a mobile phone for the front office desk. The electricity authority is not any better either, the hotel cannot get electricity because the transformer that was going to be used was still in the port in Djibouti. (Manager)

Another respondent described the inability of ETC to satisfy the demand to provide an Internet service to the hotel as follows:
The big problem is that the Ethiopian Telecommunications Corporation has no resources to serve the demand, six months ago we asked them to upgrade the broadband system, and the answer was "we do not have the resources to fulfil your request". We asked them again, a short time ago we were informed that they have the resources to provide the requested service, but they are in the process of implementing that at the moment. (Owner)

Interruption of telephone and Internet services are a regular occurrence and this is also true for electric power supply. The interruption of telephone services can last for months. However, ETC demands that hoteliers pay their monthly subscription for their telephone or broadband systems; faults are not rectified quickly and when rectified the fault frequently reoccurs. Nearly all respondents described the problem they faced with poor line quality, unreliable telephones, and broadband lines that create inconvenience for hotel staff and customers; for example, one interviewee described it as follows:

There is a nationwide problem, the broadband connections crash, and there is no connection. ETC officially apologises, especially if the failure is beyond the ability of ETC to fix it. We inform our customers what the problem is, it is a big problem for our customers, and they are disappointed with the service. We are sorry for the inconvenience caused by this to our customers. (Owner)

\section{Discussion of the National Level Findings}

Adoption/rejection of ICTs by small hotels and tour operators in Addis Ababa is largely due to political, socio-economic, technological and legal factors. The interviews and surveys demonstrate facilitator and resistance factors that originate from Ethiopia's environment at the national level. The national context plays a vital role in the availability and affordability of ICTs in a country. The national context is reflected in the country's PESCTEL conditions. Many researchers argue that the national context is a critical factor for telecommunication service provision (Li et al. 2005; Compaine 2001; Henisz and Zelner 2001). Norris (2001) and Compaine (2001) argue that the political factor is important in reducing or increasing the digital divide.

In his study of content generation in Africa, its availability and access, Chisenga (1999) argues that the political barrier of censorship, monopoly of the telecom sector and erratic power supply are major difficulties. Furthermore, the role of social media in the Arab 
revolution makes African countries wary of the technology (Shirky 2011; Kietzmann et al. 2011). In Ethiopia after the 2005 election the opposition claimed victory. In the disturbance following the demonstration called by the opposition, two hundred individuals lost their lives and tens of thousands of people were imprisoned. Text messaging was used to organize the demonstration and as a result, the government shut down text messaging for two years (Blunt 2007). Galal and Nauriyal (1995) and also Levy and Spiller (1996) argue that political structure plays a very important role in the structure and operation of telecommunication services in a country.

\section{Political Factors}

The adoption of ICT can have unanticipated effects. According to Soper and Demirkan (2012):

ICT adoption can have unanticipated effects that reach far beyond the scope of individuals, groups, or organizations. Mobile phones, for example, were not designed to foster democracy in emerging societies, and yet they do. The Internet was not designed to constrain corruption in emerging societies, and yet it does. What we find most fascinating is that the effects do not seem to result from any international or concerted action on the part of the users of these technologies. Rather, they seem in general to be emergent properties that arise naturally when citizens in emerging societies adopt ICTs and integrate them into their lives. (Soper and Demirkan 2012, 22)

The Ethiopian government is wary of what ICTs can do, or how they can be used in society in the light of the Arab spring. The repeated response given by various Ethiopian ministers is that "we are not ready to liberalise the telecommunication sector." Although there are elections every five years, in the current parliament there is only one opposition member. The policies are formed according to the governing party's own interests. Therefore, the policy is guided by the interests of the incumbent government that is running the country. Other researchers (Galal and Nauriyal 1995; Levy and Spiller 1996) also found that the telecommunications sector policy is significantly affected by the political structure and influence of interest groups. The major factor that affects adoption of ICT in hotel and tour operator businesses is the structure of the telecommunications sector, including the lack of competition and absence of an independent regulatory body. The question here is the extent to which ICT adoption has been affected by politics.

"Technopolitics" is about how different competing individuals or groups try to impose and act on their political goals using artefacts (Winner 1980). In his research on the adoption of two large Ethiopian ICT projects, Gagliardone (2014) conducted 92 interviews with politicians and technocrats and with other stakeholders. He argues that these projects are an extension and a means of cementing the political ideology of the government.

\section{Socio-economic Factors}

According to the Ethiopian government, the economy has been growing in double digits for the last seven to eight years. However, others dispute this. For example, IMF estimates the growth rate to be in the range of $6-8 \%$ GDP. Others argue that the development is a result of the investment from loan and aid rather than from wealth creation (Birara 2012). This level of economic growth is impressive when compared to other countries. However, other economic indicators are showing little or no improvement; for example, the human development index is the lowest in the world, with $50 \%$ of the population living in conditions of severe deprivation.

ICT can improve people's lives. However, the government has imposed a $40 \%$ tax on all ICT equipment imported into the country. This makes ICT unaffordable. Price has a significant role in the adoption of ICT, with high price acting as a resistance factor. Mokaya (2012) confirms that perception of high price by owner/managers restricts adoption. Furthermore, the general economic conditions, low GNI per capita, high level of inflation (44\% in 2008, $24 \%$ in 2012) and the devaluation of the currency by $50 \%$ makes ICT very expensive in Ethiopia. Back in 2009, the cost of $128 \mathrm{~Kb} / \mathrm{s}$ broadband was 5,000 Birr (250 pounds sterling) per month. At the same time, according to the World Bank, the average yearly income of an individual was US\$1,050. The figures indicate that broadband is very expensive for small and micro hoteliers, and this acts as an adoption resistance factor. This finding concurs with another study indicating that the price of ICT products and services play a significant role in the adoption or rejection of ICT (Davis and Kanago 1998).

Adoption of ICT, in many cases, is switching old technology for new. Switching requires skills and knowledge to use the new technology effectively. Switching costs should be affordable for the adopter if switching is to occur. However, in the case of hotels in Addis Ababa, the cost is very expensive. Hence, ICT is failing to be adopted by the hoteliers. Other studies indicate similar results; for example, Shapiro and Varian (1999) 
showed that if switching costs are too expensive, then adoption will not take place.

One of the essential requirements for effective use of ICT is the availability of skilled human resources. Some of the factors that determine the diffusion of innovation are knowledge and awareness about the innovation by owners/managers. The data indicate that there is a lack of skilled human resources in the sector. Although there were two higher education institutions providing hospitality and tourism courses, the demand for the skilled human resources outstripped the number of graduates from these institutions.

According to the available United Nations Development Programme (UNDP) Gender Empowerment Measure (GEM) report of 2007/2008, one of the measures of inequality is the proportion of female legislators, senior officials and managers that occupy the managerial and decision-making senior posts. In Ethiopia females occupy $20 \%$ of the total available positions (Wakins 2008). The figures from the present study are slightly lower than the UNDP figure. These gender disparities are not any different when compared with other sectors of the economy. The result is not any different when compared to other developing countries: the findings from other studies, for example in Kenya (Suda 2002), also show that these disparities are of the same proportion.

\section{Telecommunication Factors}

Successive Ethiopian governments keep major organizations under public ownership, including telecommunications, electricity, and airline and shipping services. One of the main reasons is that profits go directly to the government treasury, giving much-needed money to support the budget. The telecommunications sector structure comprises one service provider, owned and operated by the government. The telecommunication regulatory authority regulates this monopolistic operator. However, as pointed out, the regulatory authority lacks independence. Furthermore, in a monopolistic market structure, the role of the regulatory authority is very limited. In a liberalized market structure, the main role of a regulatory authority is facilitating competition in the market. In a monopoly, the role of the regulator is unclear and ineffective in the creation of competition. In addition, in Ethiopia both the operator and the regulator report to the same government minister's office.

In the case of Ethiopia, the government chooses not to liberalize the telecommunications service. Recently the prime minister stated that the sector generates a large amount of revenue for the treasury that is used for development projects (Maasho 2013). In the past, many government officials also stated that the government was not ready to liberalize the sector (Laugh and Maasho 2013). The monopolies in the telecom and ICT sectors restrict choice and provide poor services with artificially inflated prices (Freedom House 2013). The ITU (2012) indicates that the price of broadband in Ethiopia is the second most expensive in the world. The price of a computer was more than 16 months' average salary.

In a monopoly market structure, there are likely to be shortages; the service provider may be unable to satisfy the demand. For example, there were 156,963 individuals on the waiting list for a telephone in 2004 and 18,548 in 2009. Furthermore, the telecom operator struggles to maintain the existing telephone lines: fault clearance takes weeks and sometimes months to resolve. The monopoly extends to the software and hardware suppliers of the hotel sector. CNET company provides software for hoteliers to manage their hotels. The software is mandatory for hoteliers. For small and medium hotels, affordability of such a system is important to continue trading. Furthermore, CNET upgrades its software regularly, and the upgrade price is increasing all the time. Hoteliers have no option but to upgrade, as CNET will not provide maintenance service for its old software. In addition, the software connects the hotel directly to the Inland Revenue office, where every sale is recorded on their system for Value Added Tax and other purposes. If the software system fails to connect to the Inland Revenue and if the software is not upgraded, then the hoteliers have to accept full responsibility.

Petram PLC was the only cash register supplier to the hotel and tour operator businesses. Recently another seven companies have been approved to supply and maintain hardware (Ethiopian Revenues and Customs Authority [ERCA] 2012). These cash register machines are directly connected to the ERCA office. By law, only the supplier of the cash register can carry out maintenance with the approval of ERCA.

In both of these cases, the software and hardware adoption by hoteliers and tour operators was the result of government requirements for hoteliers and tour operators. Although the policies forced hoteliers and tour operators to adopt software and hardware systems, lack of competition in the sector makes it expensive for hoteliers; it is bureaucratic, because ERCA must be informed and maintenance approved by them.

The data collected in this research indicate that different technologies are adopted to a varying degree. 
For example, mobile phones are widely adopted by hoteliers and tour operators in comparison with computers, broadband or website technologies. The mobile phone was adopted by all hoteliers and tour operators in this investigation. On the other hand, no more than $14.8 \%$ of hoteliers had adopted broadband and $12 \%$ websites. The characteristics of the technology have a significant effect on adoption. One of the factors for the adoption of the mobile phone is its ease of use and its obvious usefulness for the adopter. This result had been confirmed by other research. Davis and Kanago (1998), for example, show that perceived ease of use and perceived usefulness facilitates adoption. Furthermore, mobile phones tend to be more affordable than broadband or websites.

The data also indicate that the adoption of broadband and e-mail was facilitated as a result of network externalities. The usefulness of technological artefacts such as broadband, mobile phones and e-mail systems increases as the number of adopters increases. Other researchers also confer this result; for example, Shapiro and Varian (1999) argue that positive value created because of network externalities facilitates adoption.

\section{Legal Factors}

Consumer protection law is important to protect consumers from unfair practices by companies that have monopolistic power in the economy. For example, Ethiopian telecommunication service provision to its customers can be categorised as less than fair. It takes weeks and months to fix a faulty telephone line, but the service provider still insists on the line rental payment, although the line is faulty for a long time. Consumers cannot challenge such unbusinesslike behaviour by the service provider. If anyone attempts to do so, he or she might well be disconnected altogether.

There are small hotels that rent their business premises from the government housing agency. These hoteliers are not allowed to change any of the internal structure, including installing sockets to install electrical or ICT devices. The housing agency can evict these businesses any time it chooses. The lack of legal protection for these businesses from the housing agency affects ICT investment. This restriction coupled with lack of guarantee as to how long they can rent these premises acts as a barrier for the adoption of ICT in these small and micro hotels.

\section{Summary}

Table 4 summarizes the national level factors that affect the adoption or otherwise of ICT by hoteliers and tour operators in Ethiopia.

Table 4: List of reasons behind adoption/non-adoption, together with facilitator or resistance factors, and national level factors.

\begin{tabular}{|c|c|c|c|}
\hline ICT or Aspect of ICT & $\begin{array}{l}\text { Reasons behind } \\
\text { adoption/non- } \\
\text { adoption }\end{array}$ & $\begin{array}{l}\text { Facilitator/ } \\
\text { resistance } \\
\text { factors }\end{array}$ & $\begin{array}{l}\text { National } \\
\text { level } \\
\text { factors }\end{array}$ \\
\hline $\begin{array}{l}\text { Telecommunication } \\
\text { sector }\end{array}$ & $\begin{array}{l}\text { Monopoly, lack of } \\
\text { competition in the } \\
\text { telecommunication } \\
\text { sector }\end{array}$ & Resistance & $\begin{array}{l}\text { Political } \\
\text { policy }\end{array}$ \\
\hline $\begin{array}{l}\text { Telecommunication } \\
\text { sector }\end{array}$ & $\begin{array}{l}\text { Lack of an } \\
\text { independent } \\
\text { telecommunication } \\
\text { regulator }\end{array}$ & Resistance & $\begin{array}{l}\text { Political } \\
\text { policy }\end{array}$ \\
\hline Software & $\begin{array}{l}\text { C-net (monopoly, } \\
\text { software supplier) }\end{array}$ & Resistance & $\begin{array}{l}\text { Political } \\
\text { policy }\end{array}$ \\
\hline Hardware & $\begin{array}{l}\text { Petram (monopoly, } \\
\text { hardware supplier) }\end{array}$ & Resistance & $\begin{array}{l}\text { Political } \\
\text { policy }\end{array}$ \\
\hline ICT Tax & $\begin{array}{l}40 \% \text { import tax on } \\
\text { ICTs, } 24-44 \% \\
\text { inflation, low level of } \\
\text { GNI per capita }\end{array}$ & Resistance & $\begin{array}{l}\text { Economic } \\
\text { policy }\end{array}$ \\
\hline Broadband & $\begin{array}{l}\text { Competition among } \\
\text { hoteliers }\end{array}$ & Facilitator & $\begin{array}{l}\text { Economic } \\
\text { policy }\end{array}$ \\
\hline $\begin{array}{l}\text { ICT Users } \\
\text { demographic }\end{array}$ & Gender gap & Resistance & $\begin{array}{l}\text { Social } \\
\text { policy }\end{array}$ \\
\hline $\begin{array}{l}\text { Computer, Internet } \\
\text { and website }\end{array}$ & $\begin{array}{l}\text { Lack of knowledge } \\
\text { and awareness }\end{array}$ & Resistance & $\begin{array}{l}\text { Social } \\
\text { policy }\end{array}$ \\
\hline Broadband & $\begin{array}{l}\text { Lack of legal } \\
\text { protection for small } \\
\text { hotels }\end{array}$ & Resistance & $\begin{array}{l}\text { Legal } \\
\text { policy }\end{array}$ \\
\hline
\end{tabular}

\section{Implications of Findings Together with Limitations of the Research}

This research is limited in its geographical coverage, with data being collected only from the capital city, Addis Ababa. Only one sector of the economy is investigated. The unique characteristics of this sector's use of ICT to satisfy its customer base may not be shared by other sectors of the economy. Lack of cooperation from stakeholders is also a limitation.

However, the findings of the study lead to the understanding of the PESTL factors that determine the 
adoption and use of ICTs in the small hotel and tour operator business. The research also provides insights into facilitator or resistance factors at the micro level.

\section{Conclusion}

This research is not without limitations: the data collected are restricted to small hoteliers and tour operators in the capital city, Addis Ababa. This particular sector's unique characteristics and its tendency to use ICT to promote customer satisfaction may not be applicable to other sectors of the economy. However, the research uses primary and secondary data to reach its conclusions on the factors affecting the adoption or rejection of ICT.

As explained earlier, factors affecting the adoption of ICTs by hoteliers and tour operators can be arranged according to three levels: the individual, the organizational and the national. National level factors have a significant effect on the adoption of ICT. They determine the telecommunication market structure and the regulation mechanism, which in turn affect availability and pricing of ICT services. This paper argues that national level factors play a significant role in ICT adoption or rejection with particular reference to small hotels and tour operators in the capital of Ethiopia. These factors arise out of political, socio-economic, telecommunication and legal policies. Monopolies on ICT and on telecommunication, in particular, originate from the government's political stance. The result is poor infrastructure, limited capacity and very high prices. Kenya and Tanzania with their liberalized telecommunication systems are far more advanced. In addition, Ethiopia's economic policy imposes a $40 \%$ import tax on all ICT. This is compounded by the high level of inflation (24.1\% in 2012) (IMF 2013) in the country and the low level of GNI per capita. As a result, the price of ICT is very high compared to other countries, and high price affects adoption negatively.

The social factors include the availability of general education and the awareness or lack of awareness of new technology. The education system in place in the country does not satisfy the skilled human resource demand from the hotel and tour operator business sector. In addition, the gender gap in the sector is a reflection of the social and cultural characteristics of Ethiopian society. All of these restrict the adoption of ICT in these businesses, as does the absence of legal protection of tenancy agreements for small hotels.

The findings from this research corroborate similar research on how national policies affect the adoption of
ICT (Gagliardone 2014; Hassen and Svensson 2014). These researchers show how technology is used to implement political policies. Similarly, the research reported in this paper indicates that both the political decision on the telecommunication market structure and the economic decision to impose a $40 \%$ tax on ICT tools directly influence the adoption or non-adoption of ICT by hoteliers and tour operators.

In Ethiopia policy influences come from many directions, including international organizations such as the International Monetary Fund and the World Bank. The primary and secondary data presented in this paper show how the national political, socio-economic, telecommunication and legal contexts affect the adoption or rejection of ICT by individuals and organizations in the small hotel and tour operator sector. Since national policy affects all sectors of the Ethiopian economy in similar ways, it should be possible to extrapolate from the findings of this research. It should also be possible to extrapolate from the findings to other developing countries to a certain extent, while acknowledging that Ethiopia is unique in many ways.

\section{References}

Attewell, P. 1992. “Technology Diffusion and Organizational Learning: The Case of Business Computing." Organization Science 3 (1):1-19.

Batchelor, S., N. Scott, and D. Woolnough. 2005. "Good Practice Paper on ICTs for Economic Growth and Poverty Reduction." DAC Journal 6:27-95.

Billon, M., R. Marco, and F. Lera-Lopez. 2009. “Disparities in ICT Adoption: A Multidimensional Approach to Study the Cross-Country Digital Divide." Telecommunications Policy 33 (10/11):596-610.

Birara, A. 2012. "The Facade of Change From the Inside: Ethiopia." Accessed 12 December 2012. http://www.ethiofreedom.com /wp-content/uploads/2013/12/Part-III.pdf.

Blunt, E. 2007. "Ethiopians Getting Texting in Amharic." Accessed 10 June 2011. http://news.bbc.co.uk/1/hi/world /africa/7138128.stm.

Braathen, J., H. Attwood, and J. May. 2012. "The Role of Politics in Telecentres: Cases From South Africa." International Journal of E-Politics 3 (3):1-20.

Commission, B. 2013. The State of Broadband 2013: Universalizing Broadband. Geneva: The Broadband Commission.

Chisenga, J. 1999. "Global Information Infrastructure and the Question of African Content." Accessed 10 December 2010. http://archive.ifla.org/IV/ifla65/papers/118-116e.htm.

Cohen, W. M., and D. A. Levinthal. 1990. "Absorptive Capacity: A New Perspective on Learning and Innovation." Administrative Science Quarterly 35 (1):128-52. 
Compaine, B. M. 2001. The Digital Divide: Facing a Crisis or Creating a Myth? Cambridge, MA: MIT Press.

Davis, G., and B. Kanago. 1998. "Inflation, Inflation Uncertainty, Political Stability and Economic Growth.” Accessed 12 April 2012. http://www.sba.muohio.edu/davisgk/Research /newgrow.pdf.

Davison, W. 2012. "ZTE, Huawei To Be Awarded Ethiopian Telecommunications Contracts.” Accessed 10 November 2012. http://www.bloomberg.com/news/articles/2012-10-11/zte -huawei-to-be-awarded-ethiopian-telecommunications-contracts.

Demeke, W., and A. Olden. 2012. "Researching the Adoption of ICT in Ethiopia: A Case Study of Small Hotels in Addis Ababa." Aslib Proceedings 64 (5):519-28.

Denzin, N. K. 2006. Sociological Methods: A Source Book, 5th ed. Chicago, IL: Aldine Transaction.

ERCA (Ethiopian Revenues and Customs Authority). 2012. "Authorized Cash Register Machine Distributer." Accessed 24 September 2012. http://www.erca.gov.et/index.jsp ?id = hot_info\&page_index = intro.

Estache, A., A. Goicoechea, and L. Trujillo. 2009. "Utilities Reforms and Corruption in Developing Countries." Utilities Policy 17 (2):191-202.

Fink, C., A. Mattoo, and R. Rathindran. 2003. "An Assessment of Telecommunications Reform in Developing Countries." Information Economics and Policy 15 (4):443-66.

House, F. 2013. Freedom on the Net: Ethiopia. Washington, DC: Freedom House.

Gagliardone, I. 2014. “'A Country in Order': Technopolitics, Nation Building and the Development of ICT in Ethiopia." Information Technologies \& International Development 10 (1):3-19.

Galal, A., and B. Nauriyal. 1995. "Regulating Telecommunications in Developing Countries: Outcomes, Incentives, and Commitment.” Policy Research Working Paper no. 1520. Washington, DC: World Bank.

Gasmi, F., P. Noumba, and L. Recuero Virto. 2009. "Political Accountability and Regulatory Performance in Infrastructure Industries: An Empirical Analysis." The World Bank Economic Review 23:509-31.

Gurbaxani, V., and H. Mendelson. 1990. "An Integrative Model of Information Systems Spending Growth." Information Systems Research 1 (1):23-46.

Hassen, A. Y., and A. Svensson. 2014. "The Role of E-Commerce for the Growth of Small Enterprises in Ethiopia." Electronic Journal of Information Systems in Developing Countries 65 (1):1-20.

Henisz, W. J., and B. A. Zelner. 2001. "The Institutional Environment for Telecommunications Investment." Journal of Economics and Management Strategy 10 (1):123-47.

IMF (International Monetary Fund). 2013. World Economic Outlook. Accessed 18 October 2013. http://www.imf.org/external/pubs /ft/weo/2013/02/pdf/text.pdf.

Issa-Salwe, A., and A. Olden. 2008. "Somali Web Sites, History and Politics." Aslib Proceedings 60 (6):570-82.

ITU. 2012. "Measuring the Information Society." Accessed 20 December 2012. https://www.itu.int/ITUD/ict/publications/idi /material/2012/MIS2012_without_Annex_4.pdf.

ITU. 2013a. "Measuring the Information Society." Accessed 10 January 2014. https://www.itu.int/en/ITU-D/Statistics/Documents /publications/mis2013/MIS2013_without_Annex_4.pdf.
ITU. 2013b. "The Little Data Book on Information and Communication Technology.” Accessed 15 April 2016. https://www.itu.int/en/ITU -D/Statistics/Documents/publications/ldb/LDB_ICT_2013.pdf.

Karanasios, S., and S. Burgess. 2008. "Tourism and Internet Adoption: A Developing World Perspective." International Journal of Tourism Research 10 (2):169-82.

Kietzmann, J. H., K. Hermkens, I. P. McCarthy, and B. S. Silvestre. 2011. "Social Media? Get Serious! Understanding the Functional Building Blocks of Social Media." Business Horizons 54 (3):241-51.

Krieg, R. M. 1995. "Information Technology and Low-Income, Inner-City Communities." Journal of Urban Technology 3:1-17.

Laugh, R., and A. Maasho. 2013. "Insight: In Ethiopia, State Controls Hold Back a Waking Giant.” Accessed 18 September 2013. http://www.reuters.com/article/2013/09/17/us-ethiopia -economy-insight-idUSBRE98G0NR20130917.

Lefebvre, É., and L. A. Lefebvre. 1996. Information and Telecommunication Technologies: The Impact of Their Adoption on Small and Medium-Sized Enterprises. Ottawa: International Development Research Centre.

Levy, B., and P. Spiller. 1996. Regulations, Institutions, and Commitment: Comparative Studies of Telecommunications. Cambridge: Cambridge University Press.

Li, W., C. Z. Qiang, and L. C. Xu. 2005. "Regulatory Reforms in the Telecommunications Sector in Developing Countries: The Role of Democracy and Private Interests." World Development 33 (8):1307-24.

Maasho, A. 2013. "China's Huawei to Roll Out 4g Service in Ethiopian Capital.” Reuters, 28 November. Accessed 29 November 2013. http://www.reuters.com/article/2013/11/29 /ethiopia-telecoms-idUSL5N0JD3BK20131129.

Maiorano, F., and J. Stern. 2007. "Institutions and Telecommunications Infrastructure in Low and Middle-Income Countries: The Case of Mobile Telephony." Utilities Policy 15 (3):165-81.

Mekonnen, Y. 2013. “Poor Quality, Pricey: Ethiopia's ICT Sector Slated by UN Report.” Accessed 14 November 2013. http://addisfortune.net/articles/poor-quality-pricey -ethiopias-ict-sector-slated-by-un-report/.

Miles, M., and M. Huberman. 1994. Qualitative Data Analysis. London: Sage.

Mokaya, S. O. 2012. "The Adoption of Information and Communication Technology by Small Enterprises in Thika Municipality, Kenya." International Journal of Business and Social Science 3 (13):172-7.

Moskvitch, K. 2012. "Ethiopia Clamps Down on Skype and Other Internet Use on Tor." Accessed 10 July 2012. http://www.bbc .co.uk/news/technology-18461292.

Ng'ang'a, A. M. 2009. "Toward a Regional ICT Hub: Need for Cyber Laws in Kenya." Information Security Journal: A Global Perspective 18 (1):47-50.

Ngugi, B., M. Pelowski, and J. G. Ogembo. 2010. “M-Pesa: A Case Study of the Critical Early Adopters' Role in the Rapid Adoption of Mobile Money Banking in Kenya." Electronic Journal of Information Systems in Developing Countries 43 (3):1-16.

Norris, P. 2001. Digital Divide: Civic Engagement, Information Poverty, and the Internet Worldwide. Cambridge: Cambridge University Press. 
Raho, L. E., J. A. Belohlav, and K. D. Fiedler. 1987. “Assimilating New Technology Into the Organization: An Assessment of McFarlan and McKenney's Model." MIS Quarterly 11 (1):47-57.

Ridenour, C. S., and I. Newman. 2008. Mixed Methods Research: Exploring the Interactive Continuum. Carbondale, IL: Southern Illinois University Press.

Shapiro, C., and R. H. Varian. 1999. Information Rule: A Strategic Guide to the Network Economy. Boston, MA: Harvard Business School.

Shirky, C. 2011. "The Political Power of Social Media." Foreign Affairs 90 (1):28-41.

Silverman, D. 2005. Doing Qualitative Research: A Practical Handbook, 2nd ed. London: Sage.

Soper, D. S., and H. Demirkan. 2012. "How ICTs Affect Democracy and Corruption in Emerging Societies." IT Professional 14 (4):18-23.

Stake, R. 1996. "The Art of Case Study Research." Evaluation $2(2): 231-5$.

Stern, J., and F. Trillas. 2003. "Independence and Discretion in Telecommunications Regulation: Lessons From Independent Central Banks." Utilities Policy 11 (4):191-201.
Suda, C. 2002. "Gender Disparities in the Kenyan Labour Market: Implications for Poverty Reduction." Nordic Journal of African Studies 11 (3):301-21.

Taylor, M. R., E. S. Rubin, and D. A. Hounshell. 2003. "Effect of Government Actions on Technological Innovation for SO2 Control." Environmental Science and Technology 37 (20):4527-34.

Teddlie, C., and A. Tashakkori. 2009. Foundation of Mixed Methods Research. Thousand Oaks, CA: Sage.

United Nations Development Programme. 2008. Human Development Report 2007/2008. Accessed 29 May 2009. http://hdr.undp.org /en/media/HDR_20072008_EN_Complete.pdf.

Venkatesh, V., S. A. Brown, and H. Bala. 2013. "Bridging the Qualitative-Quantitative Divide: Guidelines for Conducting Mixed Methods Research in Information Systems." MIS Quarterly 37 (1):21-54.

Wakins, K. 2008. Human Development Report 2007/2008. Accessed 29 May 2009. http://hdr.undp.org/en/media/HDR_20072008 EN_Complete.pdf.

Williamson, J. 1994. The Political Economy of Policy Reform. Washington, DC: Institute for International Economics. Winner, L. 1980. “Do Artifacts Have Politics?” Dedalus 19 (1):121-36. 